\title{
RECTIFICATION AND PENSIONS
}

\author{
Paul S Davies
}

Pension schemes can be very complicated. They can be governed by different documents which are detailed, intricate, and subject to change over a long period of time. Inadvertent errors are inevitable. As a result, rectification is a potentially important remedy. In Lansing Linde Ltd $v$ Alber, Rimer J observed that ' $[\mathrm{t}]$ he need for the remedy is because it is a fact of life that sometimes mistakes arise in the drafting of documents which the signatories do not spot before they sign'. ${ }^{1}$

However, it is only relatively recently that attention has been given to rectification in the context of pensions. The first reported case was Lansing Linde, a decision of 1999, but there have since been a large number of claims for rectification - even on summary judgment. ${ }^{2}$ It is not entirely clear why cases on rectification do not seem to have arisen earlier. ${ }^{3}$ Perhaps the recent growth coincides with an increased awareness or vigilance of those administering or advising pension schemes. Or maybe the replacement of final salary schemes with defined contributions schemes has required a greater number of general reviews of scheme documentation, and consequently the revelation of previous mistakes. Both factors are probably significant, but it is suggested that the major reason why claims for rectification were not often brought before the late 1990s is because employers and trustees used to be able to agree an amendment between themselves that would have retrospective effect and achieve the same goal as rectification. This is no longer straightforwardly available as a result of section 67 of the Pensions Act 1995, which provides that any power to modify an occupational pension scheme 'cannot be exercised on any occasion in a manner which would or might affect any entitlement, or accrued right, of any member of the scheme acquired before the power is exercised' unless certain stringent requirements are satisfied. As a result, parties are more likely to seek relief from a court.

Huge sums of money can turn upon whether a mistake in the documentation can be rectified. Yet in important respects the law is not clear, and should be examined more closely. As Sir Terence Etherton has observed, extra-judicially, rectification in occupational pension schemes 'raises particular difficulties because in many instances (most obviously, where the exercise of a power of amendment is in issue) the legal and factual context is not a bilateral contractual one but nor are the members of

\footnotetext{
${ }^{1}$ Lansing Linde Ltd v Alber [2000] Pens LR 15 (Ch) [123].

${ }^{2}$ See Section VIII below.

${ }^{3}$ P Newman, 'Rectification and Pension Schemes' (2002) 16 Trust Law International 21.
} 
the scheme mere volunteers or donees'. ${ }^{4}$ Moreover, difficult issues of policy may arise. Whilst not granting rectification as a result of a mistake of an employer may give certain employees a windfall, large payouts could have a damaging impact on the employer's covenant and the security of other members' benefits. The law in this area has not been subjected to much analysis, ${ }^{5}$ and the aim of this chapter is to cast further light on this subject and some particularly difficult issues that arise.

\section{Rectification Will Not Be Ordered Where an Alternative Remedy is Possible}

As Lord Walker recognised in Pitt $v$ Holt, '[r]ectification is a closely guarded remedy, strictly limited to some clearly-established disparity between the words of a legal document, and the intentions of the parties to it'. ${ }^{6}$ It is, rightly, difficult to convince a court that a formal, written document should be altered as a result of a mistake. Whilst mistakes do happen, parties should be encouraged to check the documents they sign carefully and the strong presumption must be that the parties intended to be bound by the plain meaning ${ }^{7}$ of a legal instrument. 'Strong irrefragable evidence' is required to support a claim for rectification. ${ }^{8}$

Rectification will not be granted if an alternative remedy is available to the parties at common law. After all, if the common law can provide satisfactory relief to the parties then there is no reason for equity to intervene. A hard example of this point is provided by Whiteside $v$ Whiteside. ${ }^{9} \mathrm{~A}$ husband executed a deed in favour of his former wife upon dissolution of their marriage. There was a mistake in the formulation of the amount to be paid. The husband brought proceedings for rectification, but also executed a supplemental deed amending the error. The Court of Appeal refused to grant rectification because the supplemental deed resolved the issue between the parties. This was harsh

\footnotetext{
${ }^{4}$ T Etherton 'The Role of Equity in Mistaken Transactions' (2013) 27 Trust Law International 159, 163

${ }^{5}$ Although, for an overview of the cases, see D Hodge, Rectification: The Modern Law and Practice Governing Claims for Rectification for Mistake, 2nd ed (London, Sweet \& Maxwell 2015) [9-39]f.

${ }^{6}$ Pitt v Holt [2013] UKSC 26, [2013] 2 AC 108 [131].

${ }^{7}$ It has been suggested that this term is problematic: see eg L Solan, The Language of Judges (Chicago, University of Chicago Press 1993) especially ch 4; A Corbin, Corbin on Contracts (St Paul, MN, West Publishing 1960) vol 3, especially $\S 535$ and $\S 542$. But compare R Lord, Williston on Contracts, 4th edn (Rochester, Lawyers Co-operative Publishing Company 1999) §602; E Farnsworth, Contracts, 4th edn (New York, Aspen Publishers 2004) §7.7. The term also continues to be invoked judicially: eg Charter Reinsurance Co Ltd v Fagan [1997] AC 313 (HL) 384; Lloyds TSB Foundation for Scotland v Lloyds Banking Group plc [2013] UKSC 3, [2013] 1 WLR 366; Lehman Brothers International (Europe) v Lehman Brothers Finance SA [2013] EWCA Civ 188, [2014] 2 BCLC 451 [71]. See too Arnold v Britton [2015] UKSC 36, [2015] AC 1619 [15]; Royal Devon and Exeter NHS Foundation Trust $v$ Atos IT Services UK Ltd [2017] EWCA Civ 2196, [2018] 2 All ER (Comm) 535 [45]. However, where a document is ambiguous, the court may have recourse to a wider range of background factors in order to establish the proper meaning of the document; for further analysis, see David Pollard's contribution to this volume.
}

\footnotetext{
${ }^{8}$ Countess of Shelburne v Earl of Inchiquin (1784) 1 Bro CC 338, 341 (Lord Thurlow LC); see too James Hay Pension Trustees Ltd v Kean Hird et al [2005] EWHC (Ch) 1093 [81] (Lawrence Collins J).

${ }^{9}$ Whiteside $v$ Whiteside [1950] 1 Ch 65.
} 
on the husband since the supplemental deed only had prospective effect against the Revenue, whereas rectification would have had retrospective effect. But the court insisted that rectification is a narrow remedy which is 'cautiously watched and jealously exercised'. ${ }^{10}$

Voluntary amendments are not, generally, an effective substitute for rectification, especially in the context of pensions. This is partly because amendments which have retrospective effect and prejudice the position of scheme members may well fall foul of section 67 of the Pensions Act 1995. ${ }^{11}$ Moreover, parties which proceed on the basis that a court would grant rectification and so the scheme can be administered as if rectification were inevitable run a very substantial risk of being wrong. At one point there appeared to be a view that an 'equity of rectification' may arise in situations where rectification would be granted, and trustees should operate on the basis of a rectified instrument even where no application to court had been made. ${ }^{12}$ But the better view is that 'unless and until a document is rectified by an order of the Court, the document takes effect as it stands'. ${ }^{13}$ Trustees should obey the terms of the trust instrument, ${ }^{14}$ and seek rectification if the terms, by mistake, do not accurately reflect the relevant party's (or parties') intentions.

Some mistakes may be corrected by interpretation at common law. Indeed, some cases even refer to 'common law rectification'. ${ }^{15}$ But such language is dangerous and prone to mislead. There are important differences between interpretation and rectification. As Lord Neuberger said in Marley $v$ Rawlings: ${ }^{16}$

At first sight, it might seem to be a rather dry question whether a particular approach is one of interpretation or rectification. However, it is by no means simply an academic issue of categorisation. If it is a question of interpretation, then the document in question has, and has always had, the meaning and effect as determined by the court, and that is the end of the matter. On the other hand, if it is a question of rectification, then the document, as rectified, has a different meaning from that which it appears to have on its face, and the court would

\footnotetext{
10 ibid 71 (Sir Raymond Evershed MR).

11 ibid.

12 cf South West Trains Ltd v Wightman [1997] OPLR 249, [1998] Pens LR 113, [77] and [120] (Neuberger J). See eg Newman (n 3) 21, 21-22.

13 Singla v Brown [2007] EWHC 405 (Ch), [2008] 2 WLR 283 [23] (Thomas Ivory QC); see too Briggs L in Safeway Ltd v Newton [2017] EWCA Civ 1482, [2018] Pens LR 2 [26].

${ }^{14} c f$ 'judicious breaches of trust' - misguided.

15 See Westway Homes Ltd v Moore (1992) 63 P\&CR 480, 489; Holding \& Barnes Plc v Hill House Hammond Limited [2001] EWCA Civ 1334, [2002] 2 P\&CR 11 [47]; KPMG v Network Rail Structure Ltd [2007] EWCA Civ 363, [2008] 1 P\&CR 11 [48]; Chartbrook Ltd v Persimmon Homes Ltd [2009] UKHL 38, [2009] 1 AC 1101 [22]-[24].

${ }^{16}$ Marley v Rawlings [2014] UKSC 2, [2014] 2 WLR 213 [40].
} 
have jurisdiction to refuse rectification or to grant it on terms (eg if there had been delay, change of position, or third party reliance).

It is important that interpretation does not expand beyond its proper limits and engulf the equitable remedy of rectification. ${ }^{17}$ There has recently been something of a 'check' upon the liberal approach favoured by Lord Hoffmann ${ }^{18}$ to interpretation of contracts, ${ }^{19}$ and a focus upon the 'plain meaning' of written instruments helps to limit the scope of interpretation and allow room for rectification to operate. This has recently been mirrored in the context of pensions. For example, in Barnardo's v Buckinghamshire, ${ }^{20}$ Lord Hodge confirmed that a 'textual interpretation' was appropriate (rather than departing from the meaning of the text due to 'contextual' considerations). ${ }^{21}$ Lord Hodge pointed to a number of factors to support this conclusion: pension schemes are formal legal documents prepared by skilled and specialist legal draftsmen; they are not generally concluded under considerable pressures of time; they are designed to operate in the long term; they confer important rights upon members who were not party to the instrument; and members of a pension scheme may not easily be able to access legal advice or ascertain the circumstances that exist when the scheme was created. ${ }^{22}$ However, it appears that there is still scope to correct obvious 'typos' through interpretation, even in the context of pensions. ${ }^{23}$

Other avenues to correcting mistakes appear less promising. For example, the possibility of estoppel by convention was previously flirted with ${ }^{24}$ but sensibly rejected in Lansing Linde and has not arisen in the pensions context since. ${ }^{25}$ Similarly, a claim to The Pensions Ombudsman is unlikely to be effective since the Ombudsman cannot entertain class actions, ${ }^{26}$ and a non-complainant cannot be

\footnotetext{
17 P Davies, 'Rectification versus Interpretation: The Nature and Scope of the Equitable Jurisdiction' [2016] CLJ 62.

18 For an overview, see P Davies, 'The Meaning of Commercial Contracts' in P Davies and J Pila (eds), The Jurisprudence of Lord Hoffmann (Oxford, Hart 2015).

${ }^{19}$ See especially Rainy Sky SA v Kookmin Bank [2011] UKSC 50, [2011] 1 WLR 2900; Arnold v Britton (n 7). See too Lord Sumption, 'A Question of Taste: The Supreme Court and the Interpretation of Contracts' [2017] Oxford University Commonwealth Law Journal 301. cf Lord Hoffmann, 'Language and Lawyers' (2018) 134 LQR 553.

${ }^{20}$ Barnardo's v Buckinghamshire \& Ors [2018] UKSC 55, [2019] 2 All ER 175.

${ }^{21}$ See too Safeway Ltd v Newton (n 13) [23], citing BESTrustees v Stewart [2001] Pens LR 283 [33] (Neuberger J).

${ }^{22}$ Barnardo's (n 20) [14]. See further David Pollard's contribution to this volume.

${ }^{23}$ Barnardo's (n 20) [18]. See too ICM Computer Group Ltd v Stribley [2013] EWHC 2995 (Ch), [2013] Pens LR 409 (Asplin J).

${ }^{24}$ Icarus (Hertford) Ltd v Driscoll [1990] PLR 1; ITN v Ward [1997] Pens LR 131.

${ }^{25}$ Lansing Linde (n 1) [197]-[201].

${ }^{26}$ Thomas Edge v Pensions Ombudsman [2000] Ch 602.
} 
bound by a decision in the complainant's favour even where the complainant and non-complainant have the same interests. ${ }^{27}$ The intervention of a court through rectification remains desirable.

Of course, one reason why a mistake may have been made could be a breach of duty by professionals - such as lawyers - involved in the drafting and execution of the legal instrument. Such professionals may be exposed to professional negligence claims if a claim for rectification is unsuccessful or not pursued. As a result, those who made the mistake may well fund rectification proceedings in order to ensure that any losses are minimised or eradicated. Many rectification claims are therefore brought in order to mitigate losses that may arise from professional negligence claims, ${ }^{28}$ which may be especially efficient where the claims are unopposed. However, it should be remembered that the duty to mitigate loss does not go so far as to require a party to embark on a difficult piece of litigation. ${ }^{29}$

\section{Identifying the Document to be Rectified}

The nature of the document to be rectified must be clearly identified. In the pensions context, rectification claims tend to concern either the original deed setting up the trust, or a deed of amendment. The most problematic cases considered in this chapter concern the latter, but it is important to appreciate that the original trust deed may also be rectified, and this possibility will be analysed first.

Rectification requires some disparity between the terms contained in a trust deed and the intention of the party that executed it. The clearest examples are those cases where there has been a drafting error in the preparation of the final trust deed, such that it does not reflect earlier drafts. ${ }^{30}$ In such cases the mistake relates to the terms of the trust deed, as the document does not say what the settlor intended. The following passage of Brightman J in Re Butlin's Settlement Trust has been influential when considering the rectification of trusts: ${ }^{31}$

in the absence of an actual bargain between the settlor and the trustees, (i) a settlor may seek rectification by proving that the settlement does not express his true intention, or the true intention of himself and any party with whom he has bargained, such as a spouse in the case of an ante-nuptial settlement; (ii) it is not essential for him to prove that the settlement fails

\footnotetext{
${ }^{27}$ Marsh Mercer Pension Scheme v Pensions Ombudsman [2001] 16 PBLR (Ch).

${ }^{28}$ Walker v Medlicott [1999] 1 All ER 685(CA).

29 Pilkington v Wood [1953] Ch 770; Moda International Brands Limited v Gateley LLP [2019] EWHC 1326 (QB), [2019] PNLR 27 [113] (Freedman J).

${ }^{30}$ eg Re Farepak Food and Gifts Ltd [2006] EWHC 3272, [2008] BCC 22.

${ }^{31}$ Re Butlin's Settlement Trust [1976] Ch 251, 262.
} 
to express the true intention of the trustees if they have not bargained; but (iii) the court may in its discretion decline to rectify a settlement against a protesting trustee who objects to rectification.

This passage has been cited with approval on many occasions. ${ }^{32}$ In a voluntary settlement, it is generally appropriate to focus upon whether the settlor was actually mistaken. ${ }^{33}$ However, where the trust was only set up pursuant to a contract, the contractual test for rectification should be applied $^{34}$ and the intentions of both parties will usually be relevant. This will often be important in the pensions context: the trust deed is rarely entered into by the employer as a uniquely voluntary act, but after reaching agreement with the employees, generally through their representatives.

Determining the appropriate test for rectification of a contract for common mistake has provoked much controversy recently. In Chartbrook Ltd $v$ Persimmon Homes Ltd Lord Hoffmann expressed the view that a contract could be rectified for common mistake even where one party was not actually mistaken: it was sufficient that a reasonable observer would conclude, objectively, that both parties had made a common mistake. ${ }^{35}$ The other members of the House of Lords agreed with Lord Hoffmann's speech, but his Lordship's views on rectification were, strictly, obiter. This left the law in a troublesome position: should judges follow Lord Hoffmann's lead, or continue to apply the orthodox test that required both parties actually (or 'subjectively') to have made a mistake? In Daventry District Council v Daventry \& District Housing $L t d^{36}$ the parties assumed, without further argument, that the objective approach to rectification favoured in Chartbrook should be applied, and the Supreme Court frustratingly refused permission to appeal. However, in FSHC Group Holdings Ltd $\checkmark$ Glas Trust Corporation Ltd the Court of Appeal has very recently had a chance to examine common mistake rectification thoroughly, and restored traditional orthodoxy in setting out the following test: ${ }^{37}$

... we are unable to accept that the objective test of rectification for common mistake articulated in Lord Hoffmann's obiter remarks in the Chartbrook case correctly states the law. We consider that we are bound by authority, which also accords with sound legal principle and policy, to hold that, before a written contract may be rectified on the basis of a common mistake, it is necessary to show either (1) that the document fails to give effect to a prior concluded contract or (2) that, when they executed the document, the parties had a common

\footnotetext{
${ }^{32}$ See eg Day v Day [2013] EWCA Civ 280, [2014] Ch 114 [21]. See too Giles v The Royal National Institute for the Blind [2014] EWHC 1373 (Ch), [2014] STC 1631 [25].

${ }^{33} \operatorname{Day}(\mathrm{n} 32)$.

${ }^{34}$ Konica Minolta Business Solutions (UK) Ltd v Applegate [2013] EWHC 2536 (Ch) (Edward Bartley Jones QC).

${ }^{35}$ Chartbrook (n 15).

${ }^{36}$ Daventry District Council v Daventry \& District Housing Ltd [2011] EWCA Civ 1153, [2012] 1 WLR 1333.

${ }^{37}$ FSHC Group Holdings Ltd v Glas Trust Corporation Ltd [2019] EWCA Civ 1361 [176]. This decision was handed down after this chapter had been written, and at the time of writing it is understood that the respondent will seek permission to appeal to the Supreme Court.
} 
intention in respect of a particular matter which, by mistake, the document did not accurately record. In the latter case it is necessary to show not only that each party to the contract had the same actual intention with regard to the relevant matter, but also that there was an 'outward expression of accord' - meaning that, as a result of communication between them, the parties understood each other to share that intention.

Although FSHC did not concern pensions, the decision is likely to be very important in the pensions context and will be discussed further below.

The majority of claims for rectification in the pensions context concern deeds of amendment. Such deeds may be executed unilaterally, in which case the focus will generally be upon the intentions of the party executing the deed when deciding whether a mistake has been made that should be rectified. ${ }^{38}$ But often the power to amend will be given to either the employer or the trustee, and the consent of the other party will be required. Moreover, sometimes the consent of the members may also be necessary, or the power to amend can only be exercised jointly. In those situations, it is more appropriate to consider the intentions of all the relevant parties, rather than to focus exclusively upon the intention of the party with the formal power to execute the deed. Rectification is necessarily factsensitive, and courts will consider carefully the particular circumstances in which a deed was executed. For example, a power to amend might be exercised by one party taking the sole initiative, and another party giving its consent but being rather passive in the matter. Or the parties may negotiate in detail about the most appropriate way to exercise a power to amend. Some form of 'common intention' may be much more important in the second scenario than the first.

Regardless of the precise document at issue, it is important to remember that rectification is an equitable remedy. Parties cannot demand rectification as of right, and the court retains a discretion whether or not to order rectification. For example, a court may be unwilling to grant rectification if the trustee reasonably opposes the application and had accepted the office of trustee on the basis of the settlement as executed.

It should also be noted that in most claims for rectification of pension schemes, it is the employer who takes the lead. This is because it will usually be up to the employer to fund the additional liability if the mistake is not corrected. Trustees will usually be neutral or 'support' the application, without serving any substantive defence. ${ }^{39}$ The parties who may be prejudiced by rectification are the scheme members: a representative order is generally made to allow the court to take into account a considered position of the beneficiaries under the pension trust. ${ }^{40}$

\footnotetext{
${ }^{38}$ Eg Merchant Navy Officers Pension Fund Trustees v Watkins [2013] EWHC 4741 (Ch) [12] (John Martin QC).

${ }^{39}$ See eg Gallaher Ltd v Gallaher Pensions Ltd [2005] EWHC 42 (Ch), [2005] Pens LR 103.

${ }^{40}$ See Section VIII below.
} 
However, in principle there is no reason why, if the benefits documented are less generous than what had been agreed and were intended to be implemented, the trustees could not seek rectification to the apparent detriment of the employer if the latter refuses to correct the mistake. ${ }^{41}$ Indeed, the beneficiaries may also be able seek rectification. Even volunteers may claim rectification, ${ }^{42}$ and pensions scheme members are more than just mere volunteers. ${ }^{43}$

\section{Outward Expression of Accord}

The cases on rectification of amendments to pension schemes have vacillated on a supposed requirement that the claimant establish an outward expression of accord. The better view is probably that it is not necessary to do so. Where a power to amend can be exercised unilaterally, there is no reason to demand an accord with any other party. ${ }^{44}$ But a power to amend often requires the consent of the employer or trustee (depending on which of the two exercises the power) and it is controversial whether an outward expression of accord must be shown.

The first reported case on rectification of a pension scheme - Lansing Linde $v$ Alber - did favour a requirement of an outward expression of accord. That case concerned an attempt to rectify a deed which represented a poor attempt at equalisation. All nine trustees admitted to not having read the definitive deed (which was 160 pages long) before executing it, and Rimer J held that the employer had failed to show that the relevant deeds did not give effect to the intentions of the principal employer and trustees. As a result, his comments on the requirement of an outward expression of accord were strictly obiter. Nevertheless, his views were clearly expressed: ${ }^{45}$

This case is all about an amendment of the 1977 deed pursuant to clause 20(A). That provides that '[Lansing] may ... with the consent of the Trustees by Deed amend the ... [1977] Deed or by Deed or Board Resolution amend ... the rules'. Any amendment has, therefore, to be proposed, or made, by Lansing with the accord of the trustees. What is required is a bilateral, consensual transaction whose substance is equivalent, or at least very close, to that of a contract save only for the absence of consideration. I cannot see how an amendment pursuant to clause 20 could ever be validly effected except in circumstances in which there is objective evidence of the accord between Lansing and the trustees: if there is not, how can it be shown that the trustees have consented to what Lansing has proposed? Moreover, since any such amendments are potentially of great importance to the scheme members generally (to whom

\footnotetext{
${ }^{41}$ If the trustee and employer agreed to correct the mistake in such a scenario that should not fall foul of $s 67$ of the Pensions Act 1995 because it would be to the advantage, rather than the detriment, of the scheme members.

42 Thompson v Whitmore [1860] $1 \mathrm{~J} \& \mathrm{H} 268$.

${ }^{43}$ LRT Pension Fund Trustee Co Ltd v Hatt [1993] PLR 227 (Ch).

44 Watkins (n 38) [12].

${ }^{45}$ Lansing Linde (n 1) [156].
} 
Lansing owes a duty of good faith - see Imperial Group Pension Trust Ltd \& ors v Imperial Tobacco Ltd \& ors [1991] 1 WLR 589, at 597 - and for whom the trustees act as such) it is in my view essential that there should be objective evidence showing that the amendment proposed by Lansing has been consented to by the trustees; and I cannot see that the need for such evidence is any less compelling than it is in the case of a contract. The fact that an amendment pursuant to clause 20 does not involve the moving of consideration between the parties appears to me to be irrelevant. The relevant feature of a clause 20 amendment is that, just like a contract, it is a bilateral transaction, involving the need for an accord.

This approach takes the requirement of consent very seriously, treating it as tantamount to contract.

However, the approach of Rimer J was not followed by Lawrence Collins J in AMP v Barker. In that case, a deed of amendment inadvertently extended the right to take generous early retirement pensions to all classes of members, rather than to members suffering from incapacity only. There was cogent evidence of a continuing common intention of both the trustees and principal employer to improve only incapacity benefits, and not to benefit early leavers generally. The judge generously recognised that he 'had the benefit of a more elaborate argument on the requirement of common accord in a case like the present one ${ }^{46}$ than Rimer J had in Lansing Linde and continued: ${ }^{47}$

No agreement between the Principal Employer and the trustees is envisaged by the rules. The Principal Employer simply has to consent to the exercise of the power of amendment by the trustees. But the consent is not to the exercise of the power of amendment in general. The Principal Employer must consent to the actual amendments ...

Consequently, the intentions of the trustees and the Principal Employer must converge. But they do not have to agree inter se. The resolution, however cannot be rectified to reflect the intentions of the trustees when that is not also the intention of the Principal Employer, for otherwise the resolution could take a form to which the Principal Employer had not consented, and the consent of the Principal Employer is an essential part of the machinery of amendment.

This decision minimises the importance of an outward expression of accord, and simply requires that the intentions of the trustee and employer 'converge'.

Such convergence is the least that should be required. To demand anything less would strip the requirement of consent of any content. But the extent to which there will be agreement may

\footnotetext{
${ }^{46}$ AMP v Barker [2000] EWHC (Ch) 42, [2001] Pens LR 77 [64].

${ }^{47}$ ibid [64]-[65].
} 
depend upon whether there have been any serious negotiations between the parties prior to exercising the amending deed. If there has not been much discussion, then it seems overly stringent to demand an outward expression of accord. And even if there has been, the fact that 'consent' is not the same as 'bargained-for agreement' should provide sufficient basis for distinguishing the pensions context from the contractual sphere, and require only convergence rather than accord.

The majority of pensions cases have followed AMP $v$ Barker rather than Lansing Linde. ${ }^{48}$ However, some judges continue to treat the issue as unsettled where they do not need to decide the point, ${ }^{49}$ and the Court of Appeal has not been required to consider the issue. ${ }^{50}$ In IBM United Kingdom Pensions Trust Limited $v$ IBM United Kingdom Holdings Limited, ${ }^{51}$ Warren J gave what is now taken to be the leading guidance, ${ }^{52}$ even if some equivocation can still be seen. ${ }^{53}$ That case concerned the rectification of a deed of amendment made 30 years previously. Warren $\mathrm{J}$ held that there was 'a significant difference of approach in the contractual cases and a case such as the present ${ }^{54}$ and said:

There needs to be cogent evidence of the intentions of both the trustee and the employer where the power of amendment requires the consent of both. ... This is not a surprising result. In a case such as Chartbrook or Daventry, what is sought to be rectified is a contract; it makes sense that, in order to displace the contract actually made by rectifying it, there should be found a consensus, albeit not one giving rise to a legally binding agreement. In contrast, in a case such as the present, no sort of agreement is required for there to be a valid deed of amendment. What is needed is an exercise of the power of amendment by the trustee and the consent of the employer to the exercise of that power. If that is to be called a consensus, so be it, but it is a different animal from the agreement or consensus which is relevant in a contractual case.

\footnotetext{
48 Eg Gallaher (n 39) [115]; Drake Insurance v MacDonald [2005] EWHC 3287 (Ch), [2005] Pens LR 401 [34] (Warren J); ZF Lemforder UK Ltd v Lemforder UK Pension Trustee Ltd [2005] EWHC 2882 (Ch), [2006] Pens LR 85 [41] (Warren J); IBM United Kingdom Pensions Trust Limited v IBM United Kingdom Holdings Limited [2012] EWHC 2766 (Ch), [2012] Pens LR 469 (Warren J); Sovereign Trustees Ltd v Lewis [2016] EWHC 2593 (Ch), [2016] Pens LR 345 (CM Marsh); Hogg Robinson Plc v Harvey [2016] EWHC 129 (Ch), [2016] Pens LR 61 (Timothy Fancourt QC). See too Irish Pensions Trust Ltd v Central Remedial Clinic [2005] IEHC 87, [2006] 2 IR 126 [130] (Kelly J); Boliden Tara Mines Ltd v Cosgrove [2007] IEHC 60 [56]-[60] (Finlay Geoghegan J).

49 XChanging Global Insurance Systems Ltd v Clark [2005] EWHC 3389 (Ch) [15] (Hart J); Scania Ltd v Wager [2007] EWHC 711 (Ch), [2007] 50 PBLR [17] (Sir Andrew Morritt C); Colorcon Ltd v Huckell [2009] EWHC 979 (Ch), [2009] Pens LR 201 [36] (HHJ Toulmin QC), Konica Minolta Business Solutions (n 34).

${ }^{50}$ The comments of Lewison LJ in Day were obiter: (n 32) [46]-[48]. See eg Saga Group Ltd v Paul [2016] EWHC 2344 (Ch), [2016] Pens LR 329 [36]-[42] (HHJ Hodge QC).

${ }^{51}$ IBM (n 48).

52 Harvey (n 48), Lewis (n 48) [15].

${ }^{53}$ Konica Minolta Business Solutions (n 34) [35]-[36].

${ }^{54}$ IBM (n 48) [23].
} 
This stands in stark contrast with the approach adopted by Rimer J in Lansing Linde $v$ Alber. Rather than draw a close analogy with contract, Warren J held that the relevant 'consensus' is markedly different in nature.

The above passage from IBM was cited with approval by the Court of Appeal in FSHC. ${ }^{55}$ Leggatt $\checkmark \mathrm{d}$ distinguished between the pension cases and contract cases since the former do not require mutual agreement, but only approval by one party of what the other has done. As a result, an 'outward expression of accord' is only a substantive requirement in the contractual context; in the pensions context, it is sufficient that the trustees and employer independently had the same intention regarding the effect of the amendment. This is likely to prove controversial. The requirement of an outward expression of accord for rectification of a contract for common mistake stems from the decision of the Court of Appeal in Joscelyne $v$ Nissen, ${ }^{56}$ which was previously considered to be merely an evidential requirement in order to satisfy the court that a claim for rectification should be granted. ${ }^{57}$ Its elevation to a substantive requirement in a rectification claim may have hard results: if it can be proved that both $A$ and $B$ intended $X$, but the contract states $Y$, it might appear fair to rectify the contract to say $Y$ even if $A$ and $B$ did not communicate their intentions to one another.

Given the fact that a substantive requirement for an outward expression of accord may operate in a harsh manner even in the contractual context, it appears sensible for the pensions cases not to adopt a similar requirement. Nevertheless, distinguishing the pension cases on the basis that mutual agreement is not necessary may lead to very fine distinctions being drawn. After all, it has been held that it does not matter whether the power to amend is properly regarded as a joint power held jointly by the trustee and employer, or whether it is a power to be exercised by one with the consent of the other. ${ }^{58}$ Yet a distinction could be drawn between the two: whereas consent may be given without the sort of 'consensus' required for a contract, as Warren J pointed out in IBM, joint powers often will require agreement in a strong sense. If the power must be exercised jointly, should that mean that the 'outward expression of accord' does need to be established?

It is suggested that even in such circumstances an 'outward expression of accord' should not be required. A substantive requirement for an outward expression of accord may operate in a harsh manner even in the contractual context, so it appears sensible for the pensions cases not to adopt a similar requirement. Even in the context of a joint power, the agreement between trustee and employer is not contractual in nature, so it is probably preferable not to employ the requirement of an outward expression of accord at all. But none of the cases so far have concerned an actual

\footnotetext{
${ }^{55}$ FSHC (n 37) [79].

56 Joscelyne v Nissen [1970] 2 QB 86.

${ }^{57}$ Eg Munt v Beasley [2006] EWCA Civ 370 [36] (Mummery L), relying on, inter alia, Gallaher ( $\mathrm{n}$ 39) considered below.

${ }^{58}$ MacDonald (n 48) [33]. See too AMP (n 46) [64].
} 
negotiation or bargain between the trustee and principal employer. Such a case may shift a court back towards the approach of Rimer J in Lansing Linde and a closer analogy to contract. That should be resisted. The focus should really be upon whether there is a mistake in the recording of the document, such that it does not align with the relevant parties' actual intentions. The importance of an outward expression of accord should not be exaggerated. There is much force behind the suggestion that the pension cases may be useful more generally as the 'thin end of the wedge' in ridding contract law of the element of an 'outward expression of accord' more generally, ${ }^{59}$ although that prospect is unlikely in the short-term in this jurisdiction as a result of the decision in FSHC.

\section{Do Communications Between the Parties Need to 'Cross the Line'?}

Consistently with a tendency to reject a requirement for an outward expression of accord, most pensions cases which consider the point do not require reliance upon communications between the parties which cross the line from one side to another. This is sensible. After all, in some situations there may be no negotiations between the parties, and no communications from one side to the other. A good example may be IBM United Kingdom Pensions Trust Limited $v$ IBM United Kingdom Holdings Limited. ${ }^{60}$ The employer wanted to introduce changes which were optional for existing members, although compulsory for new recruits. The trustee took the reasonable view that the provision of benefits for new recruits was a matter for the employer's discretion, and that the changes did not prejudice any existing members, so was happy to take an essentially passive role. As Warren J observed, 'Without being a rubber stamp, [the Trustee] would always, or almost always, accept [the Employer's] proposals so far as benefits were concerned'. ${ }^{61}$ The lack of communications 'crossing the line' was especially understandable since there was a significant overlap between membership of the employer and trustee boards. Yet such lack of communications did not, rightly, prevent rectification.

It is helpful to remember that rectification may be granted even if there is no positive evidence that the parties did not intend to make a relevant change. As HHJ Hodge QC put it in Saga Group Ltd $v$ Paul, ' $[\mathrm{t}$ ] hat is because an intention not to make the change can be sufficiently proved by the absence of any evidence that the change was intended' ${ }^{62}$ Courts will still require 'formidable evidence ${ }^{\prime 63}$ that rectification should be granted, but this approach shows that the parties do not need to have explicitly discussed their intentions with each other for rectification to be appropriate. In FSHC the Court of Appeal insisted that shared understandings could be tacit and include understandings that were so obvious as to go without saying. ${ }^{64}$ Furthermore, the court may rely upon the parties' conduct after the

\footnotetext{
${ }^{59}$ D Maclean SC, 'Recent Developments in the Law of Rectification' (2006) 80 Australian Law Journal 427, 431.

${ }^{60}$ IBM (n 48).

61 ibid [110].

62 Saga Group (n 50) [42]. See too Industrial Acoustics Company Limited v Crowhurst [2012] EWHC 1614 (Ch), [2012] Pens LR 371 [44]-[46] (Vos J); Konica Minolta Business Solutions (n 34) [31].

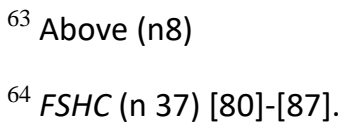


deed has been executed to support a claim for rectification. ${ }^{65}$ Such evidence may help to bolster a court's conclusions about the parties' intentions at the time of the execution of the legal instrument.

It will very often be possible to rely upon evidence of communications which have crossed the line. For instance, a practice now seems to have developed where employers and trustees prepare a 'briefing note' to explain the purpose of an amendment. That briefing note may be relied upon as strong objective evidence to show what the parties intended, and whether a mistake was made in the formal written document. Nevertheless, in some situations such helpful evidence will not be available, and it is important that the court be able to consider all useful evidence, regardless of whether it 'crossed the line'.

\section{V. 'Objective' or 'Subjective' Intentions?}

Even if it is accepted that a claim for rectification in the pensions context can be established without evidence of an outward expression of accord, or communications between parties which 'cross the line', it is still important to consider whether the focus should be upon establishing the 'objective' or 'subjective' intentions of the relevant parties. These are loaded terms which are not always helpful. But the essential difference seems to be whether a court needs to be satisfied about the appearance given by the trustees (objective intention) or what they actually thought (subjective intention).

Before the troublesome decision of the House of Lords in Chartbrook, the focus of rectification was invariably upon the subjective intentions of the parties in pensions claims. ${ }^{66}$ But Chartbrook and Daventry applied an objective approach in contract law, and this has been accepted by a number of cases in the pensions context. ${ }^{67}$ Courts have generally been able to swerve the debate by pointing out that the same result would be reached regardless of whether a subjective or objective approach is favoured, and have not expressed a firm conclusion either way. ${ }^{6}{ }^{6}$ It is unsurprising that the subjective and objective intentions of the parties will often be the same. After all, the intentions parties actually have will generally be the intentions they reasonably convey to an objective observer or reasonable addressee. But in some circumstances the subjective and objective intentions may diverge. This was seen in both Chartbrook and Daventry in the contractual context, where the courts found that rectification for common mistake should be granted, despite it being found as a matter of fact that one party was not mistaken. This has harsh results: it imposes a contract upon a party when that party did not consent to such an agreement. Indeed, this was one reason why the Court of Appeal in FSHC

\footnotetext{
${ }^{65}$ Eg Gallaher (n 39); Saga Group (n 50); Watkins (n 38).

${ }^{66}$ Eg Gallaher (n 39); MacDonald (n 48); Lemforder (n 48); and Scania (n 49).

${ }^{67}$ Eg Crowhurst (n 62) ; IBM (n 48) [15]-[17]; Unipart Group Ltd v UGC Pension Trustees Ltd [2018] EWHC 2124 (Ch), [2018] Pens LR 18 [5] (CM Marsh); St Modwen Properties Plc v Herbert [2016] EWHC 428 (Ch), [2016] Pens LR 113 (Rose J).

${ }^{68}$ See eg Pioneer GB Ltd v Webb [2011] EWHC 2683 (Ch), [2011] Pens LR 425 [23] (Sales J).
} 
sought to depart from the objective approach to common mistake rectification adopted in Chartbrook, and instead insist that both parties must actually be mistaken.

It is suggested that the decision in FSHC should be followed in the pensions context. ${ }^{69}$ Where a subjective intention can be established, that should trump any objective appearance of an intention for a rectification claim. ${ }^{70}$ Since an intention can be established even where an issue has not been discussed at all, ${ }^{71}$ it does not seem problematic to take into account evidence of the parties' actual intentions.

Indeed, this appears to have been recognised by Warren J in IBM United Kingdom Pensions Trust Limited $v$ IBM United Kingdom Holdings Limited. Although the judge accepted that Chartbrook and Daventry stated the relevant law, he went on to note that there may be 'a tension, however, between what the internal documents show and what is in fact communicated to the other party'. ${ }^{72}$ He discussed the example of the employer actually holding one intention, but innocently communicating a different intention to the trustee. If the trustee acted upon the apparent intention, but the actual intention is what was contained in the document, should the trustee be able to obtain rectification? Warren J thought the answer should be No. If the employer's actual intention could be established - even on the basis of internal documents alone which did not cross the line to the trustee (such as, perhaps, board minutes) - then there is no mistake actually shared by the parties and rectification should not be granted. This approach should be welcomed. Unless there is sharp practice, rectification should not be granted where the employer's actual intentions correspond to the contents of the written instrument. The equitable remedy of rectification operates as a 'safety valve' to the strict approach taken by the common law to interpretation, and courts should be prepared to rely upon evidence of what the parties actually thought.

\section{Determining Relevant Intentions in the Corporate Context}

It is often important to determine whose intentions are relevant for a claim of rectification. This is because both the employer and trustee may be legal persons but not natural persons. But a company, for example, cannot itself act or intend something; it acts and intends through the agency of natural

\footnotetext{
${ }^{69}$ Indeed, Leggatt $\mathrm{U}$ thought rectification should operate in a similar manner as regards both bilateral and unilateral instruments: $F S H C$ (n 37) [164]-[166].

${ }^{70}$ Unless sharp practice is involved: see unilateral mistake rectification, above. Also unless prior contract concluded, but that is unlikely in the pensions context, since often the parties will not be bound unless and until a formal, written contract is concluded.

${ }^{71}$ Above (n 64).

${ }^{72}$ IBM (n 48) [25].
} 
persons. Acts and intentions of natural persons can be attributed to a company. Attribution raises a host of difficulties, ${ }^{73}$ which have often been overlooked in the context of rectification. ${ }^{74}$

In the well-known decision of the Privy Council in Meridian Global Funds Management Asia Ltd $v$ Securities Commission, ${ }^{75}$ Lord Hoffmann broke away from the strictures of requiring an individual to be identified as the 'directing mind and will' of a company for his or her acts or intentions to be attributed to the company. ${ }^{76}$ Actors who cannot be identified as such may still have their acts and intentions attributed to the company.

In Meridian, Lord Hoffmann influentially said that there are primary, general and special rules of attribution. ${ }^{77}$ Primary rules of attribution will generally be found in a company's constitution. They need to be supplemented by general rules of attribution which are equally applicable to natural persons. These may be found in the general principles of agency. The primary and general rules will often suffice, but in some circumstances there may be a rule of law which excludes attribution on the basis of general principles of agency, in which case the court must fashion a special rule of attribution. Such special rules require close attention to the context and purpose of the rule at issue, often regarding statutory liability.

Identifying which individual's intention should represent the intention of the company for the purposes of rectification might involve recourse to the primary, general or special rules of attribution, depending on the context. ${ }^{78}$ It is important to appreciate that principles of agency law are therefore not necessarily conclusive when determining whose intention should count. Particularly acute problems can arise where the mistake is made by a person with no apparent or actual authority to bind their principal to a contract. ${ }^{79}$

Where an agent is authorised to bind the company and does so the position is generally straightforward. For example, if the board is authorised by the company's constitution to enter into a contract, and does so under a mistake - perhaps reflected in the minutes of a board meeting - then it

\footnotetext{
${ }^{73}$ See eg S Worthington, 'Corporate attribution and agency: back to basics' (2017) 133 LQR 118 (and a response by P Watts, 'Actual authority: the requirement for an agent honestly to believe that an exercise of power is in the principal's interests' [2017] Journal of Business Law 269).

${ }^{74}$ For an initial attempt to deal with some of the difficulties in the contractual sphere, see P Davies, 'Agency and Rectification' (2020) LQR (forthcoming).

${ }^{75}$ Meridian Global Funds Management Asia Ltd v Securities Commission [1995] AC 500.

${ }^{76}$ cf Lennard's Carrying Co Ltd v Asiatic Petroleum Co Ltd [1915] AC 705, 713 (Viscount Haldane LC).

${ }^{77}$ Meridian (n 76) 506-7.

${ }^{78}$ See eg Bilta (UK) Ltd (In Liquidation) v Nazir [2015] UKSC 23, [2016] AC 1.

${ }^{79}$ See Davies (n 75).
} 
is clear why a rectification claim may succeed.$^{80}$ However, in some unusual circumstances the correct approach may not be so straightforward. As Sir Terence Etherton C observed in Day v Day, ${ }^{81}$ 'the doctrine of rectification is concerned with intention, or rather the mistaken implementation of intention, rather than the power and authority to effect a particular transaction' ${ }^{82}$ That case concerned a voluntary disposition rather than a bilateral contract. Mrs Day granted a general power of attorney to her solicitor. The solicitor then conveyed property from Mrs Day to Mrs Day and one of her sons, Terence, as beneficial joint tenants. Upon Mrs Day's death, her other children sought rectification of the conveyance since Mrs Day did not intend Terence to acquire any beneficial interest in the property. The trial judge held that what the solicitor did was within the scope of his authority, and since he was not mistaken rectification should not be ordered. But the Court of Appeal allowed the appeal, and insisted that the relevant intention for rectification was that of the principal, Mrs Day. That was because she was the true 'decision maker', ${ }^{83}$ rather than the solicitor. On the basis that Mrs Day was the person who truly decided to enter into the conveyance of the property, the decision is sensible. ${ }^{84}$ It highlights that even if an agent is authorised, a contrary 'superior' intention of the principal may trump that of the agent. ${ }^{85}$

Day $v$ Day was perhaps unusual in that the intentions of the principal and agent were different. Often, where the agent is authorised to enter into a contract and does so, the principal will not have any relevant intention as to the particular terms of the contract, and will not be considered to be the true 'decision maker'. In such circumstances, the relevant intention for the purposes of rectification will be that of the agent. It is important to ascertain who the true decision-maker is. ${ }^{86}$

This was one issue that Warren J had to decide in IBM United Kingdom Pensions Trust Limited $v$ IBM United Kingdom Holdings Limited. ${ }^{87}$ Both the principal employer and scheme trustee were

\footnotetext{
${ }^{80}$ Eg George Cohen, Sons \& Co Ltd v Docks \& Inland Waterways Executive (1950) 84 Lloyd's Rep 97. Of course, the other party to the contract must share or at least know of the mistake; if unaware of the mistake made by the board, as a general rule the counterparty to the contract will be protected by the 'indoor management rule': Royal British Bank v Turquand (1856) 6 E\&B 327; Companies Act 2006 s 40.

${ }^{81} \operatorname{Day}(\mathrm{n} 32)$.

82 ibid [25]. See too Lewison LJ at [38]: 'equity intervenes not on the ground of lack of authority but on the ground of a failure of intention'.

${ }^{83}$ ibid [37] (Lewison L).

${ }^{84}$ Although whether Mrs Day's intentions were sufficiently clear has been questioned: F Dawson, 'Rectification of Voluntary Settlements' (2014) 130 LQR 356.

${ }^{85}$ cf Daventry (n 36).

${ }^{86}$ Eg Thomas Bates \& Sons Ltd $v$ Wyndham's (Lingerie) Ltd [1981] 1 WLR 505. See too Hawksford Trustees Jersey Limited as Trustee of the Bald Eagle Trust v Stella Global UK Limited [2012] EWCA Civ 55, [2012] 2 All ER (Comm) 748, which has been cited with approval in claims for rectification involving pension schemes: see eg Girls Day School Trust v GDST Pension Trustees Ltd [2016] EWHC 1254 (Ch), [2016] Pens LR 181; Saga Group (n 50) [44].

${ }^{87}$ IBM (n 48) [94]-[110].
} 
corporate bodies. As discussed above ${ }^{88}$ the employer wanted to rectify a deed of amendment and the trustee played a passive role in allowing the employer to take what it considered to be appropriate action. Decisions regarding pensions were delegated by the employer's board of directors to a management committee, which played the active role in taking decisions. However, changes to the pension scheme were 'powers reserved' to the ultimate parent company of the employer. Warren J considered whose intentions should be relevant for the rectification claim: the board of the parent company, or of the management committee? The judge adopted a robust approach in favouring the latter. On the facts, Warren J found that the 'powers reserved' did not deprive the employer or its management committee of the power or authority to make its own corporate decisions. The relevant 'decision-maker' as regards the pension scheme was the management committee, so the intentions of its board were crucial for any claim for rectification. Interestingly, the judge said that the position may be different if the management committee knew, or ought to have known, of non-compliance with the 'powers reserved' and consequent power of the parent company to make decisions. That perhaps highlights that the relevant decision-maker whose intentions should be attributed to a company can be fact-specific.

A further problem which does not yet appear to have been considered is what approach should be taken if the members of the board are not unanimous, or act with different intentions. It is common to find reference to the 'collective intention of the board' ${ }^{89}$ but it may be possible to establish that some members of the board were mistaken and some were not. This can produce tricky situations, especially if different individuals have made different mistakes with different effects in the context of a majority decision. In principle, it is suggested that rectification should only be granted if strong evidence is produced to show that a mistake has been made in recording the intention of the majority of the board, and rectification would align the written instrument with the intention of the majority of the board.

One final aspect of IBM is worth noting. Having decided that the deed executed in 1983 should be amended, Warren J then needed to determine whether subsequent deeds and rules should be rectified as well. ${ }^{90}$ The most important of these occurred in 1990, when the decision-makers were significantly different from those of 1983. The judge thought that it is not necessarily the case that earlier intentions continue unchanged; the relevant intentions need to be determined as a question of fact. On the facts, Warren J found that neither the employer nor the trustee had intended to make any material change to the early retirement provisions, and simply intended to continue what was already in place. He concluded that 'a serial error contained in successive deeds is capable of elimination by serial rectification'.91

\footnotetext{
${ }^{88}$ See Section V.

${ }^{89}$ Eg Watkins (n 38) [12].

${ }^{90}$ IBM (n 48) [399]-[459].

91 ibid [414]. See too CIT Group (UK) Ltd v Gazzard [2014] EWHC 2557 (Ch) (Barling J).
} 


\section{Defences}

There are various defences generally available to claims for rectification. Most importantly, rectification will not be granted to the prejudice of a bona fide purchaser for value without notice who takes an interest conferred by the instrument, ${ }^{92}$ and laches or acquiescence will bar the claim. ${ }^{93}$ Where rectification is sought of a voluntary settlement and one of the trustees objects, the court may in its discretion refuse rectification. ${ }^{94}$

In the context of pensions, a very long time may elapse between the execution of the relevant documents and the claim for rectification. For example, in Gallaher Ltd v Gallaher Pensions Ltd 17 years had passed..$^{95}$ But that did not bar rectification. The cases have consistently held that mere delay without any prejudice to the members is unlikely to bar rectification. ${ }^{96}$ And if the scheme has been administered as was intended, rather than in accordance with an instrument drafted in error, it is unlikely that any prejudice would be suffered.

More tricky is the potential defence of bona fide purchaser. After all, members have given value in return for their pensions, and are not mere volunteers. Nevertheless, when this defence has been run on behalf of members it has not been successful. For example, in AMP v Barker Lawrence Collins $\mathrm{J}$ held that the beneficiaries gave no value for any additional benefits erroneously conferred upon them, ${ }^{97}$ and this was supported by Etherton J in Gallaher Ltd v Gallaher Pensions Ltd. ${ }^{98}$ Admittedly, in Citifinancial Europe PLC v Davidson ${ }^{99}$ David Halpern QC, sitting as a Deputy High Court Judge, found this 'slightly surprising' but on balance the approach in AMP $v$ Barker should be supported. If there is truly no value given for the extra benefits that would be conferred under the mistakenly drafted instrument, then the fact that scheme members have given value for some 'lesser' entitlements should not prevent rectification absolutely.

\footnotetext{
92 Bell v Cundall (1750) Amb 101; Garrard v Frankel (1862) 30 Beav. 445; Coates v Kenna (1873) 7 IR Eq 113; and see Smith v Jones [1954] 1 WLR 1089 (Ch); Thames Guaranty Ltd v Campbell [1985] QB 210, 240, citing this passage.

${ }^{93}$ Beale $v$ Kyte [1907] 1 Ch 564 (holding that time runs from discovery of the mistake); McCausland $v$ Young [1949] NI 49; cf Dormer v Sherman (1966) 110 SJ 171, 172. See also Milton Keynes Borough Council v Viridor (Community Recycling MK) Ltd [2017] EWHC 239 (TCC), [2017] BLR 216 [100]-[111].

${ }^{94}$ Re Butlin's (n 31), 262.

${ }^{95}$ Gallaher (n 39) [146].

${ }^{96}$ Lemforder (n 48) [94]; Unipart v UGC (n 68).

${ }^{97} \mathrm{AMP}(\mathrm{n} 46)[72]-[77]$.

${ }^{98}$ Gallaher (n 39).

${ }^{99}$ Citifinancial Europe PLC v Davidson [2014] Pens LR 625 (Ch) [11].
} 


\section{Summary Judgment}

It has become common for parties to apply for summary judgment for the rectification of pension documents. ${ }^{100}$ This is understandable: applications are often unopposed, and this procedure is cheaper and quicker than proceeding to a full trial. Indeed, members may not oppose the application on the grounds that rectification best serves the interests of the members as a whole, and dealing with the claim through summary judgment reduces the drain on the scheme's resources.

However, one interesting and controversial issue which has arisen through dealing with matters at the stage of summary judgment concerns the court's approach to advice given to the members. For claims to be resolved by summary judgment, the employer, trustee, and representative of the members invariably agree that the application should not be opposed. If the application is opposed, the summary judgment procedure is unlikely to be appropriate. As part of this procedure, courts have developed a tendency to have the position of the representative beneficiaries of the scheme explained to the court by means of a confidential opinion from counsel of at least ten years' standing. ${ }^{101}$ This is permitted under the Chancery Practice Guide ${ }^{102}$ and allows the judge to have a confidential discussion with counsel. As Chief Master Marsh explained in Unipart Group Ltd v UGC Pension Trustees Ltd: ${ }^{103}$

... the representative party provides the court with a confidential opinion about the merits of the application. It is to my mind a useful procedure in a case that is undefended because it brings to the hearing a degree of stringency which might not otherwise be there if the hearing is dealt with on the basis of submissions in open court. It is helpful for the court to be able to explore possible gaps in the approach adopted by the claimants or the evidence which they have brought to bear.

The provision of a confidential opinion is allied with the opportunity to have a private conversation with counsel who appears for the representative party, at which, in the absence of the other parties, a candid discussion with the court can take place. If the court has any concerns, they can be explored but, more importantly, it gives the representative party the opportunity to raise points of concern given that it is rare (particularly in a claim for

\footnotetext{
${ }^{100}$ Eg Davidson (n 100); Lewis (n 48); Saga Group (n 50); Herbert ( $\mathrm{n}$ 68); Webb (n 69),; Scania (n 49); Colorcon ( 49); Crowhurst (n 62); Girls Day School Trust (n 87); Unipart v UGC (n 68).

${ }^{101}$ See eg Scania (n 49); Re Mysis Ltd [2012] EWHC 4250 (Ch) (Briggs J); Crowhurst (n 62) (Vos J); Konica Minolta Business Solutions (n 34).

102 HM Courts and Tribunals Service, Chancery Guide (2016) [29.96].

${ }^{103}$ Unipart v UGC (n 68) [8]-[9].
} 
rectification) for the application of the principles to the evidence to lead to an entirely black or white outcome; always bearing in mind that the remedy is a discretionary one.

This approach has recently been challenged. In Girls Day School Trust v GDST Pension Trustees $L t d$, Norris J insisted that the mere fact that the parties wanted to keep the advice privileged 'does not preclude the Court from taking the view that after judgment the evidence ought to be 'open' and in particular available for inspection by scheme members on the Court file'. ${ }^{104}$ Ultimately, however, the judge did not order disclosure of the opinion in that particular case. ${ }^{105}$ That is because the evidence presented in the case, even without the opinion, was full, scrutinised, and tested in open court. Moreover, all the relevant facts were set out in the full judgment of the court, and it was a straightforward case.

Importantly, Norris J also said that he was influenced by the fact that when writing the opinion counsel would not have been contemplating the disclosure of the opinion outside a very small circle. The judge put future parties on warning that disclosure may well be ordered in subsequent cases. The principle of open justice is important. He said: ${ }^{106}$

For the future any party seeking to rectify a mistake in the expression of a pension scheme by obtaining an order for summary judgment without a hearing must understand that it is likely that the Court will insist that after judgment all evidence be open to inspection: and that if this is not acceptable then the application for summary judgment must be listed for a public hearing...

The judgment of Norris J has prompted very different responses. In Saga Group Ltd v Paul HHJ Hodge QC offered robust support for the important principles of transparency and open justice, ${ }^{107}$ whereas in Sovereign Trustees Ltd $v$ Lewis CM Marsh thought the confidential procedure useful and acceptable. ${ }^{108}$ Saga Group Ltd $v$ Paul was heard after Sovereign Trustees Ltd $v$ Lewis, although judgment in the former case was handed down first. In Saga Group Ltd v Paul, the judge said that hearing the evidence in public had three significant advantages: ${ }^{109}$

\footnotetext{
${ }^{104}$ Girls Day School Trust (n 87) [17].

105 ibid [49]-[51].

106 ibid [50] (emphasis in the original).

107 Saga Group (n 50).

108 Lewis (n 48).

${ }^{109}$ Saga Group (n 50) [18].
} 
(1) it complies with the presumption that matters should be heard in public and avoids the fact that any departure therefrom is anomalous; (2) it avoids the practical difficulties of retaining a copy of the confidential opinion on the electronic court file; and (3) it avoids the issues concerning the inspection of the confidential opinion by an affected member or person claiming through them that so affected the views of Norris J in The Girls' Day School Trust case.

These are powerful considerations, although they did not persuade CM Marsh to abandon the approach he adopted in Sovereign Trustees Ltd v Lewis in Unipart Group Ltd v UGC Pension Trustees $L t d .{ }^{110}$ But given that, where the summary judgment procedure is used, the members will have already accepted that there is no reason for them to oppose the application, it does not seem prejudicial for them to reveal their advice. As the judge said in Saga Group Ltd v Paul, '[o]ne's hand has already been revealed by acknowledging that an application for summary judgment will not be opposed'. ${ }^{111}$ If summary judgment is refused that is most likely to be because the judge has identified a new point not previously considered, and not in the opinion given to the members anyway. Disclosing the opinion allows justice to be seen to be done transparently, which is particularly important where there has been no public hearing, and should be encouraged.

\section{Conclusion}

The rectification of pension schemes raises important questions. It is to be hoped that they will soon be addressed by an appellate court to provide a greater degree of certainty. Interestingly, pensions cases have been relied on in leading decisions on rectification of contracts ${ }^{112}$ and voluntary settlements, ${ }^{113}$ but with controversial results. The context of pension schemes are important to consider, although ultimately the law concerning the rectification of legal instruments should largely be aligned. Where a document fails to record the parties' actual intentions, rectification should, in principle, be available, subject to any defences and the discretion of the court to grant rectification on terms.

\footnotetext{
${ }^{110}$ Unipart v UGC (n 68). See above.

111 Saga Group (n 50) [20].

${ }^{112}$ Eg Munt v Beasley (n 57).

${ }^{113}$ Eg Day (n 32).
} 